\title{
Aflatoxin M1 in UHT Cow Milk samples Collected in Burdur, Turkey
}

\author{
Türkiye Burdur Ilinden Toplanan UHT Süt Örneklerinde Aflatoksin $M_{1}$ Kontaminasyon Düreyi
}

\section{(iD)Murat BAYEZİT ${ }^{1}$, (Delinay Başak ERDEMLİ KÖSE2*, (Datma ŞAHİNDOKUYUCU KOCASARI $^{3}$}

${ }^{1}$ Burdur Mehmet Akif Ersoy University, Faculty of Health Sciences, Department of Aid and Disaster Management, Burdur, Turkey

2 Burdur Mehmet Akif Ersoy University, Faculty of Arts and Sciences, Department of Chemistry, Burdur, Turkey 3 Burdur Mehmet Akif Ersoy University, Faculty of Veterinary Medicine, Departement of Pharmacology and Toxicology, Burdur, Turkey

\begin{abstract}
Aflatoxins are secondary metabolites of toxigenic moulds of the Aspergillus species. Aflatoxin $\mathrm{M}_{1}$, a metabolite of the potent carcinogen aflatoxin $\mathrm{B}_{1}\left(\mathrm{AFB}_{1}\right)$ occurs in milk of animals consuming feed contaminated with $\mathrm{AFB}_{1}$. The aim of this study was to investigate the occurrence and levels of aflatoxin $\mathrm{M}_{1}\left(\mathrm{AFM}_{1}\right)$ in UHT milk samples consumed in Burdur city markets. In 2018, a total of 78 UHT milk samples were randomly collected from different markets of Burdur. The occurrence and contamination levels of $\mathrm{AFM}_{1}$ in the samples were investigated by the competitive enzyme-linked immunosorbent assay (ELISA) method. Aflatoxin $\mathrm{M}_{1}$ was detected in 24 of 78 samples (30.77\%) in concentrations between 4.30-127.44 ng/L (mean level: $47.54 \mathrm{ng} / \mathrm{L}$ ). $\mathrm{AFM}_{1}$ levels in 11 of these 24 positive samples were above legal limits of Turkey which is $50 \mathrm{ng} / \mathrm{L}$ for milk samples. It is concluded that the occurrence of $\mathrm{AFM}_{1}$ in milk samples in particular may be considered as a possible hazard for public health.
\end{abstract}

Keywords: Aflatoxin $\mathrm{M}_{1}$, UHT milk, Burdur, contamination level.

Öz: Aflatoksinler, toksijenik küflerden Aspergillus türleri tarafindan sentezlenen sekonder metabolitlerdir. Aflatoksin $\mathrm{M}_{1}\left(\mathrm{AFM}_{1}\right)$, potansiyel bir kanserojen olan aflatoksin $\mathrm{B}_{1}\left(\mathrm{AFB}_{1}\right)$ ile kontamine yemlerin hayvanlar tarafindan tüketilmesi sonucunda, $\mathrm{AFB}_{1}$ 'in bir metaboliti olarak süte geçer. Bu çalışmanın amacı, Burdur marketlerinden toplanan UHT süt örneklerinde $\mathrm{AFM}_{1}$ varlığ1 ve düzeylerini araştırmaktır. Burdur'un farklı marketlerinden 2018 y1lında rastgele

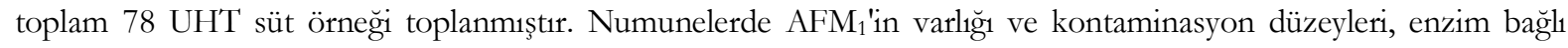
immunoabsorbent assay (ELISA) metodu ile ölçülmüştür. Aflatoksin $\mathrm{M}_{1} 78$ örneğin 24'ünde (\% 30.77) 4.30-127.44 ng/L (ortalama: $47.54 \mathrm{ng} / \mathrm{L}$ ) düzeyleri arasında tespit edilmiştir. Pozitif örneklerin 11'inde AFM 1 düzeyleri, Türkiye'de süt örnekleri için $50 \mathrm{ng} / \mathrm{L}$ olarak belirlenen yasal sınırın üstünde bulunmuştur. Özellikle süt örneklerinde AFM1 varlığının halk sağlığı için olası bir tehlike olarak kabul edilebileceği sonucuna varılmıştır.

\begin{tabular}{lc}
\hline \multicolumn{2}{l}{ Anahtar Kelimeler: Aflatoksin $\mathrm{M}_{1}$, UHT süt, Burdur, kontaminasyon düzeyi. } \\
\hline${ }^{*}$ Corresponding author : Selinay Başak ERDEMLI & e-mail : sberdemli@mehmetakif.edu.tr \\
KÖSE & \\
Geliş tarihi / Received : 26.02.2019 & Kabul tarihi / Accepted: 25.03.2019 \\
\hline
\end{tabular}

\section{Introduction}

Aflatoxins are secondary metabolites of toxigenic moulds of the Aspergillus species including Aspergillus flavus, Aspergillus paraziticus and Aspergillus nomius (Creppy, 2002; Bilandzic et al., 2016). The term aflatoxin refers to six main compounds known as Aflatoxin $\mathrm{B}_{1}\left(\mathrm{AFB}_{1}\right)$, Aflatoxin $B_{2}\left(A_{F B}\right)$, Aflatoxin $G_{1}\left(A F G_{1}\right)$, Aflatoxin $\mathrm{G}_{2}\left(\mathrm{AFG}_{2}\right)$, Aflatoxin $\mathrm{M}_{1}\left(\mathrm{AFM}_{1}\right)$ and Aflatoxin $\mathrm{M}_{2}\left(\mathrm{AFM}_{2}\right)$. Among them, $\mathrm{AFB}_{1}$ is the most synthesized and therefore the most abundant 1

To cite this article: Bayerit M, Erdemli Köse SB, Şabindokuyucu Kocasarn F. (2019). Aflatoxin Mt in UHT cow milke samples in Burdur, Turkey. MAKU J. Health Sci. Inst., 7(1), 1- 7 .

ISSN: 2148-2837/MAKU J. Health Sci. Inst. 
and toxic compound in nutrients. This is followed by $\mathrm{AFG}_{1}, \mathrm{AFB}_{2}, \mathrm{AFG}_{2}$. Aflatoxin $\mathrm{M}_{1}$ and $\mathrm{AFM}_{2}$ are the milk-extracted metabolites of $\mathrm{AFB}_{1}$ and $\mathrm{AFB}_{2}$, respectively. Aflatoxin $\mathrm{M}_{1}$ is the major monohydroxylated derivative of $\mathrm{AFB}_{1}$ formed in liver by cytochrome P450 enzymes (Price et al., 1993; Rustom, 1997; Oguz and Kurtoglu 2000; Zinedine et al., 2007).

Aflatoxin $\mathrm{M}_{1}$ is passed into milk by feeding the animals in lactation with feed containing $\mathrm{AFB}_{1}$ and it is also found in dairy products. Infection of aflatoxin into milk and milk products occurs in two ways. The first one is the passing of toxins into the milk of the animals eating the food contaminated with aflatoxin and the second one is the result of the milk and milk products being contaminated with molds (Marth, 1979; Whitlow et al., 2000). Approximately $0.3-6.2 \%$ of the $\mathrm{AFB}_{1}$ taken by the animals is discarded as $\mathrm{AFM}_{1}$. It is reported that this ratio varies depending on the animal, the amount of $\mathrm{AFB}_{1}$ taken by the feed, the lactation period and the milk quantity. In addition, it is stated that the contamination with $\mathrm{AFM}_{1}$ in milk and dairy products varies according to geographical regions, countries and seasons (Van Egmond and Paulch, 1986; Galvano et al., 1996; Pittet, 1998). Aflatoxin $\mathrm{M}_{1}$ is detected in milk 1224 hours after $\mathrm{AFB}_{1}$ is taken by animals. It has been reported that the amount of $\mathrm{AFM}_{1}$ passed into the milk by stopping the removal of $\mathrm{AFB}_{1}$ by animals is below the detectable level within 72 hours (Van Egmond, 1989).

Aflatoxins cause liver cancer in humans and animals and, particularly suppress the immune system leading to the emergence of many diseases. Both $\mathrm{AFB}_{1}$ and $\mathrm{AFM}_{1}$ cause DNA damage, gene mutation, and abnormal chromosomes in mammalian cells, insects, bacteria in vitro (Lin et al., 2004). International Agency for Research on Cancer (IARC) classifies $\mathrm{AFB}_{1}$ in Group I and $\mathrm{AFM}_{1}$ in the Group 2B carcinogens (IARC, 2002). For these reasons, $\mathrm{AFM}_{1}$ levels, which are allowed to be found in milk and milk products in our country and in some countries, especially in the US and European countries, have been determined.
$\mathrm{AFM}_{1}$ level which are allowed in milk is $500 \mathrm{ng} / \mathrm{L}$, $50 \mathrm{ng} / \mathrm{L}$ and $50 \mathrm{ng} / \mathrm{L}$ in USA, EU and Turkey, respectively (Food and Drug Administration (FDA), 1996; European Comission (EC), 2006; Turkish Food Codex (TFC), 2011).

Milk and milk products are important sources of protein and calcium for humans, especially infants and children. Therefore, intensive studies have been conducted on the presence of $\mathrm{AFM}_{1}$ in milk and dairy products. Infants and children are more sensitive to aflatoxins than adults are. The main reasons for this are the low body weight of infants and children, faster metabolism, poor detoxification ability and inadequate development of some tissues and organs. Excessive consumption of milk and milk products, especially by infants and children of developmental age increases the severity of the situation (Akdemir and Altintas, 2004; Lee et al., 2009; Sherif et al., 2009).

The aim of this study was to detect the levels of $\mathrm{AFM}_{1}$ in ultra-high temperature (UHT) milk samples in Burdur and to compare the results with legal regulations for $\mathrm{AFM}_{1}$.

\section{Material and Methods}

In 2018, 78 samples of UHT cow milk (the commercial serial numbers of the samples are not the same) were collected randomly from different markets of Burdur. All these samples were stored at $+4{ }^{\circ} \mathrm{C}$ in a dark and dry place until analysis. The analyses of this research were performed in Department of Pharmacology and Toxicology.

The quantitative analysis of $\mathrm{AFM}_{1}$ in the samples was performed by competitive enzyme-linked immunosorbent assay (ELISA) method according to the procedure described by EuroProxima B.V. The Netherlands (EuroProxima B.V. Aflatoxin $\mathrm{M}_{1}$ Fast ELISA Cat No.: 5121AFMF).

Preparation of samples was conducted according to the instructions of the EuroProxima ELISA kit (EuroProxima B.V. The Netherlands). 
Cold milk samples centrifuged at $2000 \mathrm{~g}$ for $10 \mathrm{~min}$ at $+4{ }^{\circ} \mathrm{C}$. The upper fat layer was removed. Afterwards, the extracts were used in the assay.

\section{ELISA test procedure}

One hundred $\mu \mathrm{L}$ of the standard solutions and prepared samples in separate wells were added to each well mixed by priming pipettor at least 3 times. The microtiter plate was sealed and then incubated at room temperature in the dark for 30 min. At the end of incubation, the solution was discarded from the microtiter plate. The wells were washed three times with rinsing buffer. After washing steps, $100 \mu \mathrm{L}$ of the conjugate (Aflatoxin $\mathrm{M}_{1}$-HRP) was added to the wells (except blank wells) and incubated for $15 \mathrm{~min}$ at room temperature in the dark. At the end of incubation the solution was discarded from the microtiter plate, the wells were washed three times with rinsing buffer. Then, $100 \mu \mathrm{L}$ of substrate solution was added to each well and mixed thoroughly and incubated for $15 \mathrm{~min}$ at room temperature in the dark. Following this step, $100 \mu \mathrm{L}$ of the stop solution was added to each well and mixed. The absorbance was measured at $450 \mathrm{~nm}$ by an ELISA (ELX-800, Bio-Tek Instruments Inc., Winooski, VT, USA) within $15 \mathrm{~min}$.

The results were evaluated according to the computer program, prepared by EuroProxima B.V. The levels of aflatoxin standards used were 6.25, 12.5, 25, 50, 100 and $200 \mathrm{ng} / \mathrm{L}$. The detection limit of this ELISA method was $5 \mathrm{ng} / \mathrm{L}$.

\section{Results}

Aflatoxin $\mathrm{M}_{1}$ was detected in 24 of 78 samples (30.77\%) in concentrations between 4.30-127.44 $\mathrm{ng} / \mathrm{L}$ (mean level: $47.54 \mathrm{ng} / \mathrm{L}$ ). $\mathrm{AFM}_{1}$ levels in 11 of these 24 positive samples were above legal limits of Turkey which is $50 \mathrm{ng} / \mathrm{L}$ for milk samples (Table 1).

Table 1 Occurrence of $\mathrm{AFM}_{1}$ in UHT milk samples.

\begin{tabular}{lccccc}
\hline Samples & Tested $n$ & Positive $n(\%)$ & \multicolumn{2}{c}{ Contamination (ng/L) } & Exceed regulation \\
& & & Range & Mean \pm SD $^{\mathrm{b}}$ & $n(\%)$ \\
\hline UHT milk & 78 & $24(30.77)$ & $4.30-127.44$ & $47.54 \pm 35.14$ & $11(45.83)$ \\
\hline
\end{tabular}

a The Turkish limit for $\mathrm{AFM}_{1}$ is $50 \mathrm{ng} / \mathrm{L}$ in UHT milk.

b SD: Standart deviation

\section{Discussion}

Many studies have been conducted about the existence of $\mathrm{AFM}_{1}$ in various milk samples in different countries. In Turkey, researchers reported different levels of $\mathrm{AFM}_{1}$ in UHT milk samples (Unusan, 2006; Tekinsen and Eken, 2008; Var and Kabak, 2008; Gundinc and Filazi, 2009; Aydemir-Atasever et al., 2010; SahindokuyucuKocasari, 2014; Turkoglu and Keyvan, 2019).

Unusan et al. (2006) who analysed 129 milk samples, detected $\mathrm{AFM}_{1}$ between 0-543.6 ng/L (mean value: $108.17 \mathrm{ng} / \mathrm{L}$ ) concentrations in 75 $(58.1 \%)$ of samples and 61 of $129(47 \%)$ samples were above the limit permitted by the EU. Tekinsen and Eken (2008) examined 100 milk samples and found $67 \%$ of samples contaminated with $\mathrm{AFM}_{1}$ in concentrations of $10-630 \mathrm{ng} / \mathrm{kg}$ and researchers stated that $31(31 \%)$ of UHT milk samples contain $\mathrm{AFM}_{1}$ above maximum tolerable limit of the EC and the TFC. Var and Kabak (2008) analysed 20 samples of milk and found $\mathrm{AFM}_{1}$ in $100 \%$ of the samples ranged from 10 to $80 \mathrm{ng} / \mathrm{L}$ and 3 of milk samples were found to contain $\mathrm{AFM}_{1}$ higher than the tolerance of Turkish legal limits. Gundinc and Filazi (2009) observed that in all of 50 milk samples, $\mathrm{AFM}_{1}$ was detected in a concentration 5-244 ng/L (mean value: 101.2 
$\mathrm{ng} / \mathrm{L})$. Researchers found that in $10(20 \%)$ of 50 samples $\mathrm{AFM}_{1}$ levels exceed the legal limits of EC and TFC. Aydemir-Atasever et al. (2010) evaluated the occurrence of $\mathrm{AFM}_{1}$ in $59.3 \%$ of 150 samples at levels of 5-185 ng/L and $\mathrm{AFM}_{1}$ in 16 (10.7\%) of the samples were found to be higher than the maximum tolerable limits of EC and TFC. Sahindokuyucu-Kocasari (2014) analysed 30 samples of milk and found $\mathrm{AFM}_{1}$ in 30 (73.2\%) of the samples ranged from 6.42 to $71.33 \mathrm{ng} / \mathrm{L}$ (mean value: $17.76 \mathrm{ng} / \mathrm{L})$. Only in $3(7.3 \%)$ of UHT milk samples, $\mathrm{AFM}_{1}$ levels were above the Turkish legal limit (50 ng/L). Turkoglu and Keyvan (2019) analysed 35 UHT milk samples and detected mean $\mathrm{AFM}_{1}$ level as $20.29 \mathrm{ng} / \mathrm{L}$ in 97.14 $\%$ of samples and 8 of 34 positive samples were above the legal limits.

Some researchers from different countries also reported $\mathrm{AFM}_{1}$ contamination in their studies (Martins and Martins, 2000; Roussi et al., 2002; Shundo and Sabino, 2006; Shundo et al., 2009; Rahimi et al., 2009; Fallah, 2010; Heshmati and Milani, 2010; Movassagh, 2011; Rahimi et al., 2011; Oliveira et al., 2013; Zheng et al., 2013; Silva et al., 2015; Bilandžić et al., 2016).

In Portugal, Martins and Martins (2000) analysed 70 UHT milk samples and detected $\mathrm{AFM}_{1}$ in 84.2 $\%$ of the samples ranged from 5 to $61 \mathrm{ng} / \mathrm{L}$. Researchers found $\mathrm{AFM}_{1}$ which were higher than the legal limits ( $50 \mathrm{ng} / \mathrm{L}$ ) in only 2 of the samples. In Greece, Roussi et al. (2002) detected $\mathrm{AFM}_{1}$ in $82.3 \%$ of 17 milk samples at levels $5-50 \mathrm{ng} / \mathrm{L}$. None of the UHT milk samples had $\mathrm{AFM}_{1}$ level above the legal limits. In Saudi Arabia, Abdallah et al. (2012) analysed 96 milk samples and detected $\mathrm{AFM}_{1}$ in $79(82.3 \%)$ of the samples ranged from 10 to $190 \mathrm{ng} / \mathrm{L}$. In all the positive samples, levels of $\mathrm{AFM}_{1}$ were below the tolerated limits. In India, Siddappa et al. (2012) detected $\mathrm{AFM}_{1}$ in 64.4 of 45 milk samples at levels $60-700 \mathrm{ng} / \mathrm{L}$ and $38 \%$ of these positive levels were above the maximum permitted limits. Many studies have been conducted about the existence of $\mathrm{AFM}_{1}$ in various milk samples in Iran (Rahimi et al., 2009; Fallah, 2010; Heshmati and Milani, 2010; Movassagh,
2011; Rahimi et al., 2011). Rahimi et al. (2009) observed that in all of 48 milk samples $\mathrm{AFM}_{1}$ was detected in a concentration 10->100 ng/L (mean value: $65 \mathrm{ng} / \mathrm{L}$ ). Fallah (2010) found the toxin in $68(62.4 \%)$ of 109 milk samples contained in the range of 5.6-515.9 ng/L and researcher stated that $3(2.7 \%)$ of UHT milk samples had levels above the maximum tolerance limit. Heshmati and Milani (2010) detected $\mathrm{AFM}_{1}$ in 116 (55.2\%) of 210 samples ranged from 8-249 $\mathrm{ng} / \mathrm{L}$ and the levels of $\mathrm{AFM}_{1}$ in $70(33.3 \%)$ samples were higher than the maximum tolerance limit. Movassagh (2011) observed $\mathrm{AFM}_{1}$ in all of 49 milk samples at levels between 0 to $259 \mathrm{ng} / \mathrm{L}$ and $83.67 \%$ of the samples had $\mathrm{AFM}_{1}$ greater than the accepted limit of EC. Rahimi et al. (2011) analysed 59 milk samples and detected $\mathrm{AFM}_{1}$ in $91.5 \%$ of samples ranged from 10->100 ng/L. In Brazil, Shundo and Sabino (2006) detected $80.9 \%$ of 42 UHT milk samples ranged from 20-206 ng/L, Shundo et al. (2009) analysed 40 milk samples and all of the samples were contaminated with $\mathrm{AFM}_{1}$ at levels 10-500 ng/L, Oliveira et al. (2013) analysed 75 milk samples and $\mathrm{AFM}_{1}$ in $30.7 \%$ of the samples ranged from $1000-4100 \mathrm{ng} / \mathrm{L}$ which were above the tolerance limit of Brazilian regulations (500 $\mathrm{ng} / \mathrm{L}$ ) and Silva et al. (2015) detected $\mathrm{AFM}_{1}$ in 87.5 $\%$ of 152 samples at levels $1.8-121 \mathrm{ng} / \mathrm{L}$ and levels of $\mathrm{AFM}_{1}$ were below the tolerated limits. In China, Zheng et al. (2013) analysed 153 milk samples and detected $\mathrm{AFM}_{1}$ in $54.9 \%$ of samples ranged from 6 to $160 \mathrm{ng} / \mathrm{L}$ and none of the samples exceed the tolerated limit (500 ng/L). In Bosnia and Herzegovina and Croatia, Bilandžić et al. (2016) analysed 214 samples and found $\mathrm{AFM}_{1}$ in samples at levels $2.29-21.4 \mathrm{ng} / \mathrm{kg}$, levels of $\mathrm{AFM}_{1}$ were below the tolerated limits $(50 \mathrm{ng} / \mathrm{L})$.

In comparison with previous studies, the incidence and contamination levels of $\mathrm{AFM}_{1}$ in UHT milk in our study were higher than Var and Kabak (2008), and lower than Unusan et al. (2006), Shundo and Sabino (2006), Tekinsen and Eken (2008), Shundo et al. (2009), Gundinc and Filazi (2009), Fallah (2010), Heshmati and Milani (2010), Movassagh (2011), Siddappa et al. (2012). The incidence of $\mathrm{AFM}_{1}$ in UHT milk was lower, but the 
contamination levels were higher than Martins and Martins (2000), Rossi et al. (2002), Sahindokuyucu et al. (2014) and Turkoglu and Keyvan (2019). The incidence of $\mathrm{AFM}_{1}$ in UHT milk was lower and the contamination levels were similar to Rahimi et al. (2009), Aydemir et al. (2010), Rahimi et al. (2011), Abdallah et al. (2012), Zheng et al. (2013) and Silva et al. (2015). In Oliveira et al. (2013), the incidence of $\mathrm{AFM}_{1}$ in UHT milk was similar, but the contamination levels were much higher than our study.

Previous studies have reported different levels of $\mathrm{AFM}_{1}$ in UHT milk samples. On the other hand, Srivastava et al. (2001) reported that $\mathrm{AFM}_{1}$ were not detected in any of the samples. Different analytical methods, geographical region, climatic factors and seasonal variability may change results of researches (Var and Kabak 2008; Fallah 2010).

In conclusion, in UHT milk samples which are available for consumption in Burdur region, $\mathrm{AFM}_{1}$ contamination prevalence is $30.77 \%$ and 11 (14.10 $\%$ ) of samples were above the maximum limit that allowed to be present in UHT milk samples in Turkey. The presence of $\mathrm{AFM}_{1}$ in milk and dairy products is a major risk factor for public health, especially for children and infants. For this reason, it is necessary to prevent the growth of fungi and especially the synthesis of $\mathrm{AFB}_{1}$ in feed and feed raw materials both in field and in storage conditions.

\section{References}

Abdallah, M.I.M., Bazalou, M.S., Al-Julaifi, M.Z., 2012. Determination of aflatoxin $M_{1}$ in concentrations in full-fat cow's UHT milk sold for consumption in Najran-Saudi regarding its public health significance. Egyptian Journal Applied Science 27(3), 40-54.

Akdemir, C., Altintas, A., 2004. Ankara'da işlenen sütlerde aflatoksin- $\mathrm{M}_{1}$ varllğının ve düzeylerinin HPLC ile araşturilması. Ankara Üniversitesi Veteriner Fakültesi Dergisi 51, 175179.

Aydemir-Atasever, M., Adiguzel, G., Atasever, M., Ozlu, H., Ozturan, K., 2010. Occurrence of aflatoxin $\mathrm{M}_{1}$ in UHT milk in Erzurum-Turkey. Kafkas Universitesi Veteriner Fakültesi Dergisi 16, 119-122.

Bilandzic, N., Bozic, D., Đokic, M., Sedak, M., Solomun-Kolanovic, B., Varenina, I., Tankovic, S., Cvetni, Z., 2014. Seasonal effect on aflatoxin $\mathrm{M}_{1}$ contamination in raw and UHT milk from Croatia. Food Control 40, 260-264.

Bilandzic, N., Varenina, I., Solomun, B., 2010. Aflatoxin $\mathrm{M}_{1}$ in raw milk in Croatia. Food Control 21(9), 1279-1281.

Creppy, E.E., 2002. Update of survey, regulation and toxic effects of mycotoxins in Europe. Toxicology Letters 127(1-3), 19-28.

EC, 2006. Commission Regulation No 1881/ 2006 of 19 December 2006. Setting maximum levels for certain contaminants in foodstuffs. Official Journal of the European Communities 364, 5-24.

Fallah, A.A., 2010. Assessment of aflatoxin $\mathrm{M}_{1}$ contamination in pasteurized and UHT milk marketed in central part of Iran. Food and Chemical Toxicology 48(3), 988-991.

FDA, 1996. Sec. 527.400 whole milk low fat, milk skim milk aflatoxin $\mathrm{M}_{1}$ (CPG 7106.210). In FDA compliance policy guides. Washington, DC: US FDA. pp: 219.

Galvano, F., Galofora, V., Galvona, G., 1996. Occurrence and stability of aflatoxin $\mathrm{M}_{1}$ in milk and milk products: a world wide review. Journal of Food Protection 59(10), 1079-1090.

Gundinc, U., Filazi, A., 2009. Detection of aflatoxin $\mathrm{M}_{1}$ concentrations in UHT milk consumed in Turkey markets by ELISA. Pakistan Journal of Biological Sciences 12(8), 653-656.

Heshmati, A., Milani, J.M., 2010. Contamination of UHT milk by aflatoxin $\mathrm{M}_{1}$ in Iran. Food Control 21(1), 19-22.

IARC, 2002. Monograph on the evaluation of carcinogenic risk to humans. World Health Organization. Some Traditional Herbal Medicines, Some Mycotoxins, Naphthalene and Styrene. Summary of Data Reported and Evaluation, Lyon $82,171-175$. 
Lee, J.E., Kwak, B.M., Ahn, J.H., Jeon, T.H., 2009. Occurrence of aflatoxin $M_{1}$ in raw milk in South Korea using an immunoaffinity column and liquid chromatography. Food Control 20(2), 136138.

Lin, L.C., Liu, F.M., Fu, Y.M., Shih, D.Y.C., 2004. Survey of aflatoxin $M_{1}$ contamination of dairy products in Taiwan. Journal of Food and Drug Analysis 12(2), 154-160.

Marth, E.H., 1979. Aflatoxin in milk, cheese and other dairy products. Marschall Italian \& Speciality Cheese Seminars 1-18.

Martins, M.L., Martins, H.M., 2000. Aflatoxin $\mathrm{M}_{1}$ in raw and ultra high temperature-treated milk commercialized in Portugal. Food Additives and Contaminants 17(10), 871-874.

Movassagh, M.H., 2001. Presence of aflatoxin $\mathrm{M}_{1}$ in UHT milk in Tabriz (northwest of Iran). Journal of Food Safety 31, 238-241.

Oguz, H., Kurtoglu, V., 2000. Effect of clinoptilolite on performance of broiler chickens during experimental aflatoxicosis, British Poultry Science 41(4), 512-517.

Oliveira, C.P., Soares, N.F.F., Oliveira, T.V., Baffa Júnior, J.C., Silva, W.A., 2013. Aflatoxin $\mathrm{M}_{1}$ occurrence in ultra high temperature (UHT) treated fluid milk from Minas Gerais/Brazil. Food Control 30(1), 90-92.

Pittet A., 1998. Natural occurrence of mycotoxins in foods and feeds. A updated review. Revue de Medicine Veterinaire 149(6), 479-492.

Price, W.D., Lovell, R.A., McChesney, D.G., 1993. Naturally occuring toxins in feedstuffs: Center for Veterinary Medicine Perspective. Journal of Animal Sciences 71(9), 2556-2562.

Rahimi, E., Nilchian, Z., Behzadnia, A., 2011. Presence of aflatoxin $\mathrm{M}_{1}$ in pasteurized and UHT milk commercialized in Shiraz, Khuzestan and Yazd, Iran. Journal of Chemical Health Risks 1(1), 7-10.

Rahimi, E., Shakerian, A., Jafariyan, M., Ebrahimi, M., Riahi, M., 2009. Occurrence of aflatoxin $\mathrm{M}_{1}$ in raw, pasteurized and UHT milk commercialized in Esfahan and Shahr-e Kord, Iran. Food Security 1, 317-320.
Roussi, V., Govaris, A., Varagouli, A., Botsoglous, N.A., 2002. Occurrence of aflatoxin $\mathrm{M}_{1}$ in raw and market milk commercialized in Greece. Food Additives and Contaminants 19(9), 863-868.

Rustom, I.Y.S., 1997. Aflatoxin in food and feed: occurrence, legislation and inactivation by physical methods. Food Chemistry 59(1), 57-67.

Sahindokuyucu-Kocasari, F., 2014. Occurrence of aflatoxin $\mathrm{M}_{1}$ in UHT milk and infant formula samples consumed in Burdur, Turkey. Environmental Monitoring and Assessment 186(10), 6363-6368.

Sherif, S.O., Salama, E.E., Abdel-Wahhab, M.A., 2009. Mycotoxins and child health:The need for health risk assessment. International Journal of Hygiene and Environmental Health 21(4), 347-368.

Shundo, L., Navas, S.A., Lamardo, L.C.A., Ruvieri, V., Sabino, M., 2009. Estimate of aflatoxin $\mathrm{M}_{1}$ exposure in milk and occurrence in Brazil. Food Control 20(7), 655-657.

Shundo, L., Sabino, M., 2006. Aflatoxin $\mathrm{M}_{1}$ in milk by immunoaffinity column cleanup with TLC/HPLC determination. Brazilian Journal of Microbiology 37(2), 164-167.

Siddappa, V., Nanjegowda, D.K., Viswanath, P., 2012. Occurrence of aflatoxin $M_{1}$ in some samples of UHT, raw \& pasteurized milk from Indian states of Karnataka and Tamilnadu. Food and Chemical Toxicology 50(11), 4158-4162.

Silva, M.V., Janeiro, V., Bando, E., Machinski Jr, M., 2015. Occurrence and estimative of aflatoxin $\mathrm{M}_{1}$ intake in UHT cow milk in Paran a State, Brazil. Food Control 53, 222-225.

Srivastava, V.P., Bu-Abbas, A., Alaa-Basuny Al-Johar, W., Al-Mufti, S., Siddiqui, M.K.J., 2001. Aflatoxin $\mathrm{M}_{1}$ contamination in commercial samples of milk and dairy products in Kuwait. Food Additives and Contaminants 18(11), 993997.

Tekinsen, K.K., Eken, H.S., 2008. Aflatoxin $\mathrm{M}_{1}$ levels in UHT milk and kaskar cheese consumed in Turkey. Food Chemical and Toxicology 46(10), 3287-3289. 
TFC, 2011. Gida maddelerindeki belirli bulasanlarin maksimum limitleri hakkında teblig. Resmi Gazete, 29.12.2011, Sayi, 28157. Ankara Basbakanlik Basimevi, Turkey.

Turkoglu, C., Keyvan, E., 2019. Determination of Aflatoxin $\mathrm{M}_{1}$ and Ochratoxin $\mathrm{A}$ in Raw, Pasteurized and UHT Milk in Turkey. Acta Scientiae Veterinariae 47, 1626. (DOI: 10.22456/1679-9216.79176.89667).

Unusan, N., 2006. Occurrence of aflatoxin $\mathrm{M}_{1}$ in UHT milk in Turkey. Food and Chemical Toxicology 44(11), 1897-1900.

Van Egmond, H.P., 1989. Current situation on regulations of mycotoxins. Overview of tolerances and status of standart methots of sampling and analysis. Food Additives Contaminants 6(2), 139188.

Van Egmond, H.P., Paulch, V.H., 1986. Mycotoxins in milk and milk products. Netherland Milk and Dairy Journal 40, 175-188.
Var, I., Kabak, B., 2008. Detection of aflatoxin $\mathrm{M}_{1}$ in milk and dairy products consumed in Adana, Turkey. International Journal of Dairy Technology 62(1), 15-18.

Whitlow, L.W., Hagler, W.M., Hopkins, B.A., Diaz, D.E., 2000. Mycotoxins in feeds and their effects on dairy cattle. Moormoon's Feeds Facts 11(3), 1-7.

Zheng, Z, Sun, P, Wang, J.Q., Zhen, Y.P., Han, R.W., Xu, X.M., 2013. Occurrence of aflatoxin $\mathrm{M}_{1}$ in UHT milk and pasteurized milk in China market. Food Control 29(1), 198-201.

Zinedine, A., Gonzalez-Osnaya, L., Soriano, J.M., Molto, J.C., Idrissi, L., Manes, J., 2007. Presence of aflatoxin $\mathrm{M}_{1}$ in pasteurized milk from Morocco. International Journal of Food Microbiology 114(1), 25-29. 